\title{
HUBUNGAN KOMPETENSI DAN LINGKUNGAN KERJA DENGAN KINERJA PEGAWAI DINAS PEMUDA DAN OLAH RAGA DI KOTA GORONTALO
}

\author{
Abdul Rahmat \\ Fakultas Ilmu Pendidikan Universitas Negeri Gorontalo \\ Email: abdulrahmat@ung.ac.id
}

\begin{abstract}
Abstrak: Tujuan penelitian ini untuk mendeskripsikan hubungan kompetensi kompetensi dan lingkungan kerja dengan kinerja pegawai Dinas Pemuda dan Olah Raga di Kota Gorontalo. Desain penelitian ini adalah survei, untuk menguji hipotesis penelitian serta melakukan interpretasi mengenai hubungan variabel bebas dengan variabel terikat. Populasi dan sample dalam penelitian ini adalah keseluruhan pegawai Dinas Pemuda dan Olah Raga Kota Gorontalo sebanyak 47 orang. Instrumen utamanya adalah angket. Hasil penelitian menunjukkan hubungan kompetensi dengan kinerja pegawai tergolong pada katagori sangat signifikan; hubungan lingkungan kerja dengan kinerja pegawai dikatagorikan tingkat hubungan lingkungan kerja dengan kinerja pegawai dikatagorikan signifikan; hubungan kompetensi $\left(\mathrm{X}_{1}\right)$ dan lingkungan kerja $\left(\mathrm{X}_{2}\right)$ secara bersama-sama dengan kinerja pegawai $(\mathrm{Y})$ dapat dikatagorikan tingkat hubungan Kompetensi dan Lingkungan Kerja secara bersama-sama dengan Kinerja Pegawai dikatagorikan sangat signifikan.
\end{abstract}

Kata kunci: kompetensi, lingkungan, dan kinerja.

\begin{abstract}
The purpose of this study to describe the relationship of competence and work environment with employee performance Department of Youth and Sports in the city of Gorontalo. This is a survey research design, to test the hypothesis of the study and interpretation of the relationship of independent variables with the dependent variable. Population and sample in this study was overall employee in the Department of Youth and Sports Gorontalo 47 people. The main instrument was a questionnaire. The results showed: the relationship competence with employee performance belong to the category of very significant; relationship work environment with employee performance level categorized workplace relationships with significant categorized employee performance; relationship competence (X1) and work environment (X2) together with employee performance (Y) level relations Competence and Working Environment together with the very significant categorized Employee Performance.
\end{abstract}

Keywords: competence, environmental, and performance

\section{PENDAHULUAN}

Akhir-akhir ini hampir seluruh instansi pemerintah, khususnya kementerian dan lembaga, disibukkan dengan upaya mereka melakukan Reformasi Birokrasi. Tidak dapat dipungkiri bahwa banyak instansi pemerintah memiliki persepsi yang salah mengenai tujuan dari reformasi birokrasi itu sendiri. Reformasi Birokrasi lebih dipandang sebagai upaya untuk meningkatkan tunjangan kinerja, tanpa melihat upaya-upaya yang harus 
dilakukan agar organisasi lebih mampu menunjukkan kinerja. Hal ini berkembang akibat adanya banyak instansi yang hanya melihat dari sisi "terang" apa yang telah dilakukan tiga instansi pilot project reformasi birokrasi, yaitu: Departemen Keuangan, BPK dan MA, dan telah menyusul baru-baru ini Sekretariat Negara. Jika melihat dan benchmark ke dalam instansi-instansi tersebut akan diperoleh informasi bahwa pada dasarnya mereka telah banyak melakukan upaya-upaya reformasi birokasi sejak lama.

Berbagai permasalahan/hambatan yang mengakibatkan sistem penyelenggaraan pemerintahan tidak berjalan atau diperkirakan tidak akan berjalan dengan baik harus ditata ulang atau diperharui. Reformasi birokrasi dilaksanakan dalam rangka mewujudkan tata kelola pemerintahan yang baik (good governance). Dengan kata lain, reformasi birokrasi adalah langkah strategis untuk membangun aparatur negara agar lebih berdaya guna dan berhasil guna dalam mengemban tugas umum pemerintahan dan pembangunan nasional. Selain itu dengan sangat pesatnya kemajuan ilmu pengetahuan, teknologi informasi dan komunikasi serta perubahan lingkungan strategis menuntut birokrasi pemerintahan untuk direformasi dan disesuaikan dengan dinamika tuntutan masyarakat. Oleh karena itu harus segera diambil langkah-langkah yang bersifat mendasar, komprehensif, dan sistematik, sehingga tujuan dan sasaran yang telah ditetapkan dapat dicapai dengan efektif dan efisien. Reformasi di sini merupakan proses pembaharuan yang dilakukan secara bertahap dan berkelanjutan, sehingga tidak termasuk upaya dan/atau tindakan yang bersifat radikal dan revolusioner.

Berdasarkan fungsi dan tujuan birokrasi, jelas bahwa birokrasi di setiap jenjang, harus diselenggarakan secara sistematis guna mencapai tujuan tersebut. Hal tersebut berkaitan dengan pembentukan Kinerja pegawai sehingga mampu bersaing, beretika, bermoral, sopan santun dan berinteraksi dengan masyarakat. Berdasarkan penelitian di Harvard University Amerika Serikat ternyata kesuksesan seseorang tidak ditentukan semata-mata oleh pengetahuan dan kemampuan teknis (hard skill) saja, tetapi lebih oleh kemampuan mengelola diri dan orang lain (soft skill). Penelitian ini mengungkapkan, kesuksesan hanya ditentukan sekitar 20 persen oleh hard skill dan sisanya 80 persen oleh soft skill. Bahkan orang-orang tersukses di dunia bisa berhasil dikarenakan lebih banyak didukung kemampuan soft skill daripada hard skill. Hal ini mengisyaratkan bahwa mutu birokrasi Kinerja pegawai sangat penting untuk ditingkatkan (Asrin, 2011:14).

Dinas Pemuda dan Olah Raga Kota Gorontalo , dalam hal ini walikota sebagai kepala daerah sangatlah dekat dengan politik dan administrasi publik. Terlebih lagi pada sistem pemilihan kepala daerah secara langsung seperti sekarang, kedekatan kepala daerah pada aspek politik semakin kuat, selain posisinya sebagai penanggung jawab administrasi dan manajemen pemerintahan daerah. Oleh karena itu pemikiran teoretis dan praktis sebagai walikota dalam menerapkan pendekatan-pendekatan baru dalam administrasi publik. Walikota dituntut dapat memadukan secara serasi demokrasi administrasi publik. Hal tersebut tidak akan tercapai tanpa keterkaitan semua pihak yang berada dekat dengan lingkungan masyarakat agar birokrasi menjadi lebih efektif. Selain itu juga diperlukannya komunikasi, komunikasi yang baik dapat menciptakan suasana kerja yang nyaman yang memungkinkan setiap anggota organisasi dalam hal ini masyarakat dapat bekerja dan bekerjasama dengan baik. Dalam hal ini dengan terciptanya lingkungan kerja yang lancar baik secara horizontal maupun vertikal antar anggota masyarakat dengan masyarakat akan mengefektifkan didalam pengelolan masyarakat. 
Berdasarkan latar belakang dapat ditarik untuk meneliti tentang hubungan kompetensi dan lingkungan kerja dengan Kinerja pegawai Dinas Pemuda dan Olah Raga di Kota Gorontalo. Berdasarkan berbagai faktor yang diduga memiliki hubungan kompetensi dan lingkungan kerja dengan kinerja pegawai Dinas Pemuda dan Olah Raga di Kota Gorontalo, dapat diidentifikasikan sebagai berikut: (1) Apakah terdapat hubungan kompetensi dengan kinerja pegawai Dinas Pemuda dan Olah Raga Kota Gorontalo?; (2) Apakah terdapat hubungan lingkungan kerja dengan kinerja pegawai Dinas Pemuda dan Olah Raga Kota Gorontalo ?

Berdasarkan identifikasi masalah, penelitian ini dapat dirumuskan sebagai berikut: (1) Apakah terdapat hubungan kompetensi dengan kinerja pegawai Dinas Pemuda dan Olah Raga Kota Gorontalo?; (2) Apakah terdapat hubungan lingkungan kerja dengan kinerja pegawai Dinas Pemuda dan Olah Raga Kota Gorontalo ?

Penelitian ini memiliki tujuan untuk menganalisis tentang: (1) Hubungan kompetensi dengan pengembangan kinerja pegawai Dinas Pemuda dan Olah Raga Kota Gorontalo; dan (2) Hubungan lingkungan kerja dengan kinerja pegawai Dinas Pemuda dan Olah Raga Kota Gorontalo.

Hasil dari penelitian ini diharapkan dapat memberi kegunaan sebagai berikut:

1. Dari segi Teoritis: (a) Penelitian ini diharapkan memeberi masukan untuk mengembangkan konsep tentang hubungan kompetensi dan lingkungan kerja dengan kinerja pegawai Dinas Pemuda dan Olah Raga Kota Gorontalo.; (b) Adanya analisis dan pembuktian hubungan kompetensi dan lingkungan kerja dengan kinerja pegawai Dinas Pemuda dan Olah Raga Kota Gorontalo.

2. Dari segi praktis: (a) Penelitian ini diharapkan dapat digunakan sebagai bahan masukan dalam hubungan kompetensi dan lingkungan kerja dengan kinerja pegawai Dinas Pemuda dan Olah Raga Kota Gorontalo.; (b) Bagi Dinas terkait sebagai bahan referensi dalam menentukan kebijakan mengenai hubungan kompetensi dan lingkungan kerja dengan kinerja pegawai Dinas Pemuda dan Olah Raga Kota Gorontalo.

\section{KAJIAN TEORI}

Kinerja Pegawai. Rajasa (2007:15) memberikan definisi tentang kinerja (performance) sebagai berikut : "Performance is defined as the record of autcomes produced on a specified job function or activity during a specified time period "(kinerja adalah catatan tentang hasil-hasil yang diperoleh dari fungsi-fungsi pekerjaan tertentu atau kegiatan tertentu selama kurun waktu tertentu). Definisi ini menekankan kinerja sebagai hasil atau apa yang keluar (outcome) dari sebuah pekerjaan dan kontribusi pegawai terhadap organisasi.

Mangkunegara, (2007:9), Kinerja adalah hasil kerja secara kualitas dan kuantitas yang dicapai oleh seorang karyawan dalam melaksanakan tugasnya sesuai dengan tanggung jawab yang diberikan kepadanya. Definisi tersebut menyatakan bahwa kinerja adalah apa yang dihasilkan oleh seorang karyawan dalam melaksanakan tugas yang diberikan kepadanya. Ruky (2002:20), menyatakan bahwa kinerja adalah hasil kerja yang meliputi beberapa aspek yaitu : 1) Quality of Work, 2) Promptness, 3) Initiative, 4) capability, dan 5) communication yang dijadikan ukuran dalam mengadakan pengkajian tingkat kinerja seseorang. Dari definisi tersebut dikatakan bahwa kinerja merupakan hasil 
kerja seseorang yang meliputi beberpa aspek yaitu kualitas kerja, ketepatan waktu, inisiatif, kemampuan dan komunikasi.

Sharker (2006:35), mendefinisikan kinerja sebagai hasil kerja karyawan yang meliputi aspek : 1) Kuantitas, yaitu jumlah yang harus diselesaikan atau dicapai. Pengukuran kuantitatif melibatkan perhitungan keluaran dari proses atau pelaksanaan kegiatan. Ini berkaitan dengan jumlah keluaran yang dihasilkan; 2) Kualitas, yaitu mutu yang harus dihasilkan (baik tidaknya). Pengukuran kualitatif keluaran mencerminkan pengukuran "tingkat kepuasan", yaitu seberapa baik penyelesaiannya. Ini berkaitan dengan bentuk keluaran; 3) Ketepatan waktu, yaitu sesuai tidaknya dengan waktu yang direncanakan. Pengukuran ketepatan waktu merupakan jenis khusus dari pengukuran kuantitatif yang menentukan ketepatan waktu penyelesaian suatu kegiatan.

Menurut Hasibuan dalam Nawawi (2006:62) menyatakan bahwa kinerja adalah hasil yang dicapai seseorang dalam melaksanakan tugas-tugas yang dibebankan kepadanya berdasarkan kecakapan, pengalaman, kesungguhan dan waktu. Selanjutnya dikatakan juga bahwa hasil kerja merupakan gabungan dari tiga faktor yang terdiri dari minat dalam bekerja, penerima delegasi tugas, peran dan tingkat motivasi seorang pekerja. Semakin tinggi ketiga faktor tersebut dalam bekerja maka semakin baik kinerja seseorang.

Supeni (2012:45) menjelaskan kinerja merupakan aplikasi dari nilai-nilai kepemimpinan yang mengedepankan harmoni dan keselarasan, bagaimana menyelesaikan konflik, serta mempunyai sikap arif dan bijaksana. Wirawan (2009:5) mendefinisikan kinerja sebagai keluaran yang dihasilkan oleh fungsi-fungsi atau indikator-indikator suatu pekerjaan atau suatu profesi dalam waktu tertentu.

Soeprihanto (2007:1) mendefinisikan bahwa kinerja adalah hasil kerja selama periode tertentu dibandingkan dengan berbagai kemungkinan misalnya standar kerja, target, sasaran atau kriteria yang telah ditentukan terlebih dahulu dan telah disepakati bersama. Nawawi (2006:66-67), kinerja dapat diartikan sebagai apa yang dikerjakan (hasil kerja) seorang karyawan dalam melaksanakan tugas-tugas pokoknya. Dalam pengertian praktis berarti indikator kinerja dalam melaksanakan pekerjaan pada sebuah organisasi yang mencakup lima unsur yaitu kuantitas hasil kerja yang dicapai, kualitas hasil kerja yang dicapai, jangka waktu mencapai hasil kerja tersebut, kehadiran dan kegiatan selama hadir di tempat kerja dan kemampuan bekerja sama.

Berdasarkan teori-teori di atas maka disimpulkan bahwa kinerja adalah hasil kerja yang diperlihatkan seorang individu dalam melaksanakan tugasnya untuk mencapai tujuan organisasi dalam kurun waktu tertentu. Berdasarkan kesimpulan maka dirumuskan indikator kinerja yaitu:1) Kuantitas hasil kerja; 2) Kualitas hasil kerja; 3) Waktu penyelesaian pekerjaan; 4) Pencapaian standar kerja; 5) Tanggung jawab terhadap pekerjaan.

Kompetensi (Variabel X1). Edgar (2009:140) merumuskan pengertian kompetensi sebagai "Demonstrable characteristics of a person that enable performance of a job". Karakteristik tersebut mencakup pengetahuan dan keterampilan teknis dan antarpribadi individu. "Competence encompasses an individual's technical and interpersonal knowledge and skills.

Gerald (2004:62) merumuskan pengertian kompetensi sebagai "The knowledge, skills and qualities of effective managers / leaders". Sedangkan rumusan yang lebih luas dikemukakan oleh Boyatzis, yaitu sebagai sesuatu yang mendasari karakteristik seseorang, 
dapat berbentuk motif, ciri, keterampilan, aspek dari citra-pribadi, atau peran sosial seseorang, atau sebuah kumpulan pengetahuan yang ia gunakan.

Dari uraian di atas dapat disimpulkan bahwa konsep kompetensi mencakup semua aspek dari kinerja pekerjaan. Ini mencakup kinerja pada tingkat keterampilan yang akseptabel, pengorganisasian tugas-tugas seseorang, menanggapi dan bereaksi secara memadai apabila menghadapi kesalahan, memenuhi peran dalam rencana kerja serta mengalihkan keterampilan dan pengetahuan ke situasi-situasi yang baru.

Lingkungan Kerja (Variabel X2). Edgar Schein (2002:98) mengemukakan bahwa lingkungan kerja dapat dibagi ke dalam dua dimensi yaitu :

(1) Dimensi external environments; yang didalamnya terdapat lima hal esensial yaitu: (a) mission and strategy; (b) goals; (c) means to achieve goals; (d) measurement; dan (e) correction.

(2) Dimensi internal integration yang di dalamnya terdapat enam aspek utama, yaitu: (a) common language; (b) group boundaries for inclusion and exclusion; (c) distributing power and status; (d) developing norms of intimacy, friendship, and love; (e) reward and punishment; dam (f) explaining and explainable : ideology and religion.

Arif (2010:476), lingkungan kerja juga dipengaruhi oleh nilai-nilai dan sikap-sikap moral yang disebut utilitarianisme. Ruky (2002:63), ada enam karakteristik penting dari lingkungan kerja, yaitu : (1) obeserved behavioral regularities; yakni keberaturan cara bertindak dari para anggota yang tampak teramati. Ketika anggota organisasi berinteraksi dengan anggota lainnya, mereka mungkin menggunakan bahasa umum, istilah, atau ritual tertentu; (2) norms; yakni berbagai standar perilaku yang ada, termasuk di dalamnya tentang pedoman sejauh mana suatu pekerjaan harus dilakukan; (3) dominant values; yaitu adanya nilai-nilai inti yang dianut bersama oleh seluruh anggota organisasi, misalnya tentang kualitas produk yang tinggi, absensi yang rendah atau efisiensi yang tinggi; (4) philosophy; yakni adanya kebijakan-kebijakan yang berkenaan dengan keyakinan organisasi dalam memperlakukan pelanggan dan karyawan (5) rules; yaitu adanya pedoman yang ketat, dikaitkan dengan kemajuan organisasi (6) organization climate; merupakan perasaan keseluruhan (an overall "feeling") yang tergambarkan dan disampaikan melalui kondisi tata ruang, cara berinteraksi para anggota organisasi, dan cara anggota organisasi memperlakukan dirinya dan pelanggan atau orang lain

Lingkungan kerja dapat dipandang sebagai sebuah sistem. Dilihat dari sisi in put, budaya organisasi mencakup umpan balik (feed back) dari masyarakat, profesi, hukum, kompetisi dan sebagainya. Sedangkan dilihat dari proses, budaya organisasi mengacu kepada asumsi, nilai dan norma, misalnya nilai tentang : uang, waktu, manusia, fasilitas dan ruang. Sementara dilihat dari out put, berhubungan dengan Hubungan budaya organisasi Dengan perilaku organisasi, teknologi, strategi, image, produk dan sebagainya.

Dilihat dari sisi kejelasan dan ketahanannya dengan perubahan, John P. Kotter dan James L. Heskett (1998:34) memilah lingkungan kerja menjadi ke dalam dua tingkatan yang berbeda. Dikemukakannya, bahwa pada tingkatan yang lebih dalam dan kurang terlihat, nilai-nilai yang dianut bersama oleh orang dalam kelompok dan cenderung bertahan sepanjang waktu bahkan meskipun anggota kelompok sudah berubah. Pengertian ini mencakup tentang apa yang penting dalam kehidupan, dan dapat sangat bervariasi dalam perusahaan yang berbeda : dalam beberapa hal orang sangat mempedulikan uang, dalam hal lain orang sangat mempedulikan inovasi atau kesejahteraan karyawan. Pada 
tingkatan ini budaya sangat sukar berubah, sebagian karena anggota kelompok sering tidak sadar akan banyaknya nilai yang mengikat mereka bersama. Pada tingkat yang terlihat, lingkungan menggambarkan pola atau gaya perilaku suatu organisasi, sehingga karyawan-karyawan baru secara otomatis terdorong untuk mengikuti perilaku sejawatnya. Sebagai contoh, katakanlah bahwa orang dalam satu kelompok telah bertahun-tahun menjadi "pekerja keras", yang lainnya "sangat ramah Dengan orang asing dan lainnya lagi selalu mengenakan pakaian yang sangat konservatif. Budaya dalam pengertian ini, masih kaku untuk berubah, tetapi tidak sesulit pada tingkatan nilai-nilai dasar.

\section{METODE}

Penelitian ini dilaksanakan pada bulan september 2013 Dinas Pemuda dan Olah Raga Kota Gorontalo. Desain penelitian ini adalah survei, yaitu penelitian yang mengambil sampel dari satu populasi dan menggunakan kuesioner sebagai alat pengumpulan data yang pokok. Desain ini ditujukan untuk menguji hipotesis penelitian serta melakukan interpretasi mengenai Hubungan variabel bebas Dengan variabel terikat. Desain ini ditujukan untuk menguji hipotesis penelitian serta melakukan interpretasi mengenai Hubungan variabel bebas Dengan variabel terikat, yaitu kompetensi (K) dan lingkungan kerja (LK), Dengan variabel Kinerja Pegawai (KP).

Unit Analisis, Populasi, Sampel dan Responden. Unit analisis adalah satuan tertentu yang diperhitungkan sebagai subyek penelitian, Arikunto, (2002:81). Maka unit analisis dalam penelitian ini adalah pegawai di Dinas Pemuda dan Olah Raga Kota Gorontalo. Dalam menentukan besarnya ukuran sampel dari populasi tersebut, penulis menggunakan teknik atau cara penentuan sampel dengan cara sempel total atau sensus, yang berjumlah sebanyak 47 orang pegawai di Dinas Pemuda dan Olah Raga Kota Gorontalo.

Jenis data yang digunakan dalam penelitian ini berasal dari 2 (dua) sumber utama yaitu: (1) Data primer, yaitu keseluruhan data hasil penelitian yang diperoleh melalui pengisian angket. (2) Data sekunder, yaitu data yang diperoleh dari instansi terkait dan studi literatur dan studi dokumentasi, terutama yang berkaitan dengan masalah penelitian ini.

Teknik Pengumpulan Data. Untuk mengumpulkan berbagai data, keterangan dan informasi, maka digunakan teknik pengumpulan data melalui angket dan studi kepustakaan. Daftar pertanyaan yang bersifat tertutup dimana setiap pertanyaan sudah disediakan alternatif jawaban yang dibagikan kepada responden, kemudian responden dapat memilih salah satu alternatif jawaban yang dianggap sesuai dengan kenyataan.

Instrumen Penelitian. Penulis menggunakan instrumen penelitian yang berbentuk angket. Adapun format jawaban dari angket ini yaitu menggunakan metode Skala Peringkat (Rating Scale) dengan 5 (lima) alternatif jawaban diberi skor. Untuk memperoleh skor data dari variabel-variabel penelitian ini digunakan instrumen dalam bentuk kuesioner dan menggunakan skala peringkat dengan rentang skor dari yang paling rendah sampai yang paling tinggi yaitu antara $1 \mathrm{~s} / \mathrm{d} 5$. Dengan demikian terdapat tiga macam instrumen yang menjaring data dalam penelitian ini yakni instrumen mengukur variabel Kompetensi, instrumen yang mengukur variabel Lingungan Kerja dan instrumen yang mengukur variabel Kinerja Pegawai. 
Teknik Analisis Data. Analisis terhadap data hasil pengukuran Kinerja Pegawai yang diperoleh melalui kegiatan penelitian ini adalah analisis deskriptif dan inferensial. Analisis deskriptif dalam kegiatan penelitian ini dimaksudkan untuk melakukan perhitungan terhadap harga rata-rata, simpangan baku, atau standar deviasi, pembuatan distribusi frequensi, modus, median, serta untuk deskripsi dalam bentuk histogram dari skor hasil pengumpulan data yang diperoleh melalui penggunaan angket.

Penggunaan analisis inferensial untuk mendapatkan perhitungan dan pengujian hipotesis, serta untuk kepentingan generalisasi hasil penelitian. Sebelum melakukan pengujian hipotesis, maka terlebih dahulu diadakan lagi persyaratan analisis yang meliputi uji normalitas data hasil penelitian dengan menggunakan uji Liliefors dan uji homogenitas varians populasi dengan menggunakan uji Bartlett, setelah uji persyaratan analisis diuji dengan menggunakan uji korelasi product moment dan koefisien korelasi kuadrat.

\section{HASIL DAN PEMBAHASAN}

Berdasarkan data hasil penelitian di lapangan (data empiris) dengan bantuan statistika atau teknik analisis data, maka dapat dipaparkan hasil penelitian di lapangan dan hasil analisis data serta pembahasan hasil penelitian. Hasil penelitian akan dipaparkan dalam bentuk statistika deskriptif untuk masing-masing variabel penelitian deskriptif data hasil penelitian meliputi : skor tertinggi, skor terendah, rata-rata (mean), nilai yang sering muncul pada jawaban responden (modus), nilai tengahnya (median), varians sampel, simpangan baku (standar deviasi).

Selanjutnya pengujian dengan data penelitian akan dilakukan dari segi pengujian persyaratan analisis untuk korelasi Product Moment Pearson, pengujian hipotesis penelitian, dan pembahasan hasil penelitian serta keterbatasan penelitian. Berdasarkan hasil anaisis dengan menggunakan SPSS deskriptif statistik dapat dilihat pada Tabel berikut ini:

Tabel 1. Deskriptif Statistik

\begin{tabular}{|c|c|c|c|c|}
\hline & & $\begin{array}{c}\text { Kompetensi } \\
\text { Manajerial }\end{array}$ & Lingkungan Kerja & Kinerja Pegawai \\
\hline & Valid & 47 & 47 & 47 \\
\hline $\mathrm{N}$ & Missing & 0 & 0 & 0 \\
\hline Meal & & 137.1915 & 143.6809 & 151.6170 \\
\hline Med & & 138.0000 & 146.0000 & 152.0000 \\
\hline Mod & & $136.00^{\mathrm{a}}$ & 144.00 & 150.00 \\
\hline Std. & viation & 11.31878 & 9.99588 & 11.58814 \\
\hline Varic & & 128.115 & 99.918 & 134.285 \\
\hline Rang & & 65.00 & 52.00 & 77.00 \\
\hline Mini & & 83.00 & 104.00 & 86.00 \\
\hline $\operatorname{Max}$ & & 148.00 & 156.00 & 163.00 \\
\hline Sum & & 6448.00 & 6753.00 & 7126.00 \\
\hline
\end{tabular}

Deskripsi Data Variabel Kompetensi Pegawai. Berdasarkan Tabel 1 dapat dilihat bahwa rata-rata variabel kinerja 137,19, median 138, modus 136 dan simpangan bakunya 11,32. 
Untuk memperjelas deskriptif data pada variabel Kompetensi ini dapat dilihat Gambar 1 sebagai berikut :

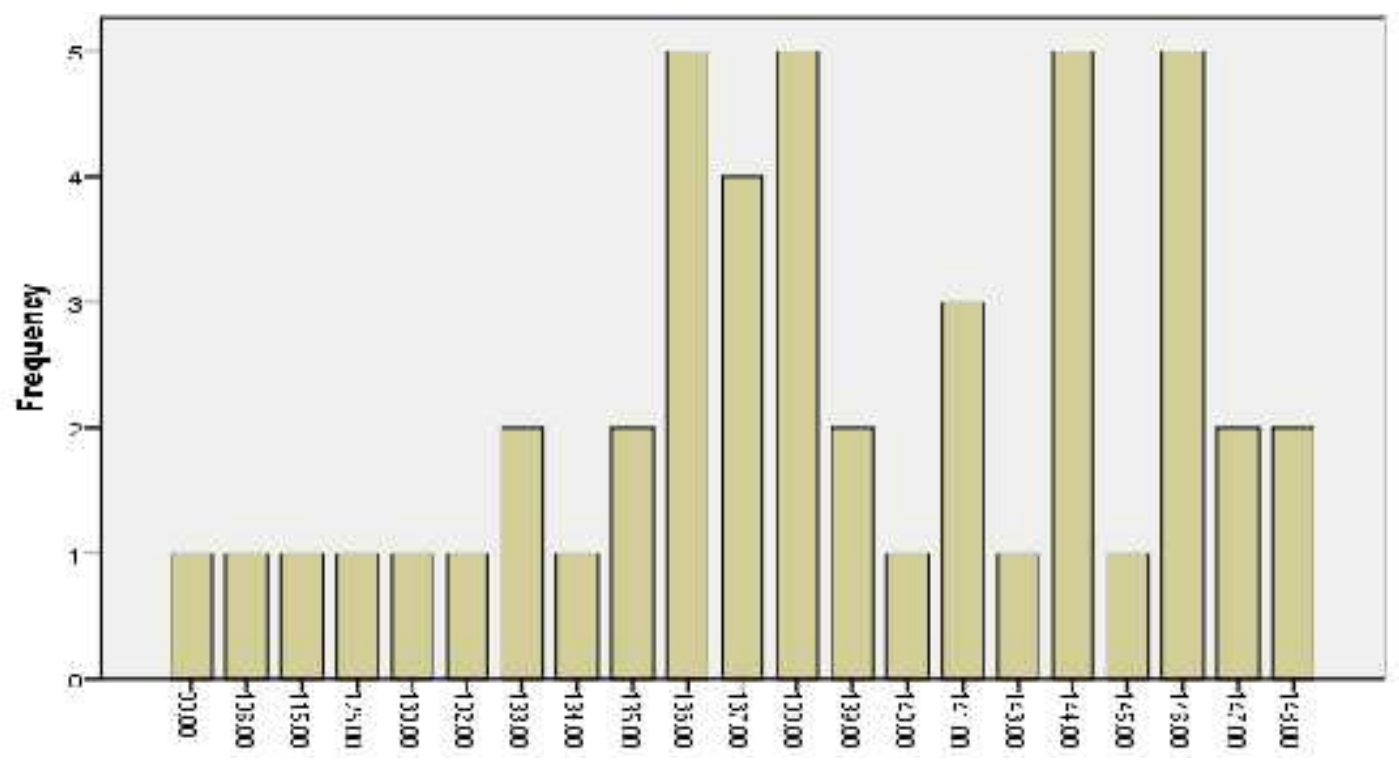

Gambar 1. Grafik Batang Variabel Kompetensi

Berdasarkan Gambar 1 dapat dijelaskan bahwa frekuensi terkecil sebesar 1 atau $2,1 \%$ terdapat pada nilai $83,106,115,125,130,132,134,140,143$, dan 145 . Selanjutnya frekuensi terbesar sebesar 5 atau 10,6\% terdapat pada nilai 136, 138, 144, dan 146.

Deskripsi Data Variabel Lingkungan Kerja. Berdasarkan Tabel 1 dapat dilhat bahwa rata-rata variabel kinerja 143,68, median 146, modus 144 dan simpangan bakunya 9,99. Untuk memperjelas deskriptif data pada variabel Lingkungan Kerja dapat dilihat Gambar 2 sebagai berikut

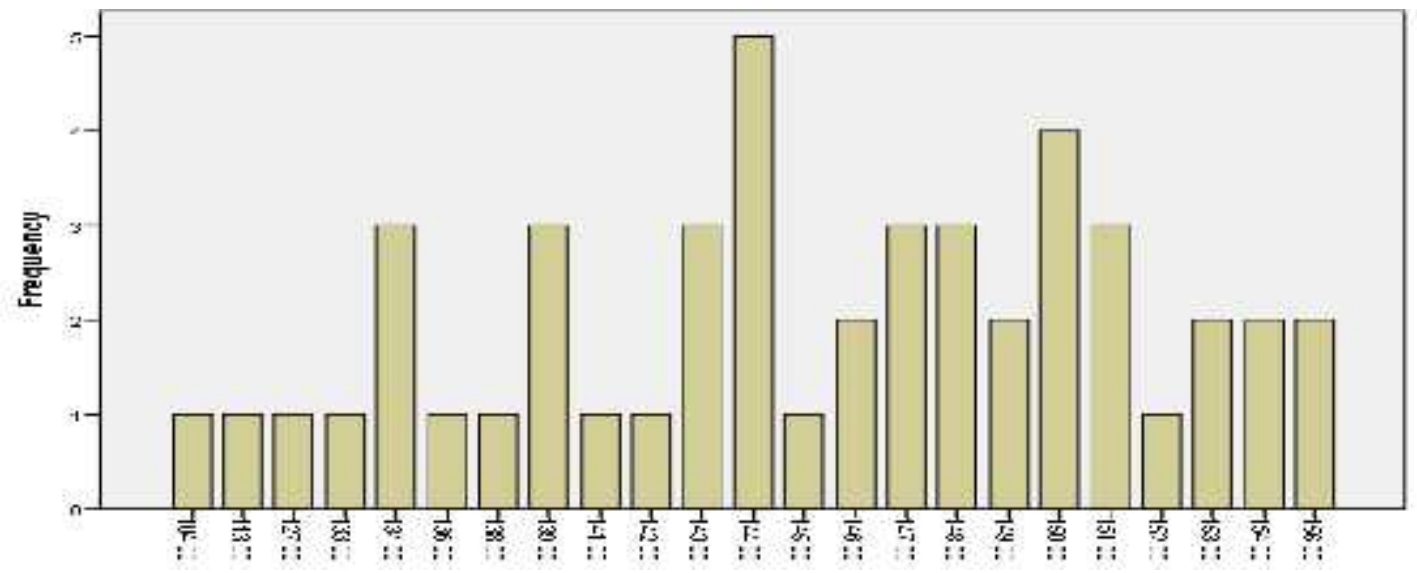

Gambar 2. Grafik Batang Variabel Lingkungan Kerja 
Berdasarkan Gambar 2 dapat dijelaskan bahwa frekuensi terkecil sebesar 1 atau $2,1 \%$ terdapat pada nilai $104,113,127,133,136,138,141,142,145$ dan 152 . Selanjutnya frekuensi terbesar sebesar 5 atau 10,6\% terdapat pada nilai 144 .

Deskripsi Data Variabel Kinerja Pegawai. Berdasarkan Tabel 1 dapat dilhat bahwa ratarata variabel kinerja 151,62 median 152, modus 150 dan simpangan bakunya 11,59. Untuk memperjelas deskriptif data pada variabel Kinerja Pegawai dapat dilihat Gambar 3 sebagai berikut :

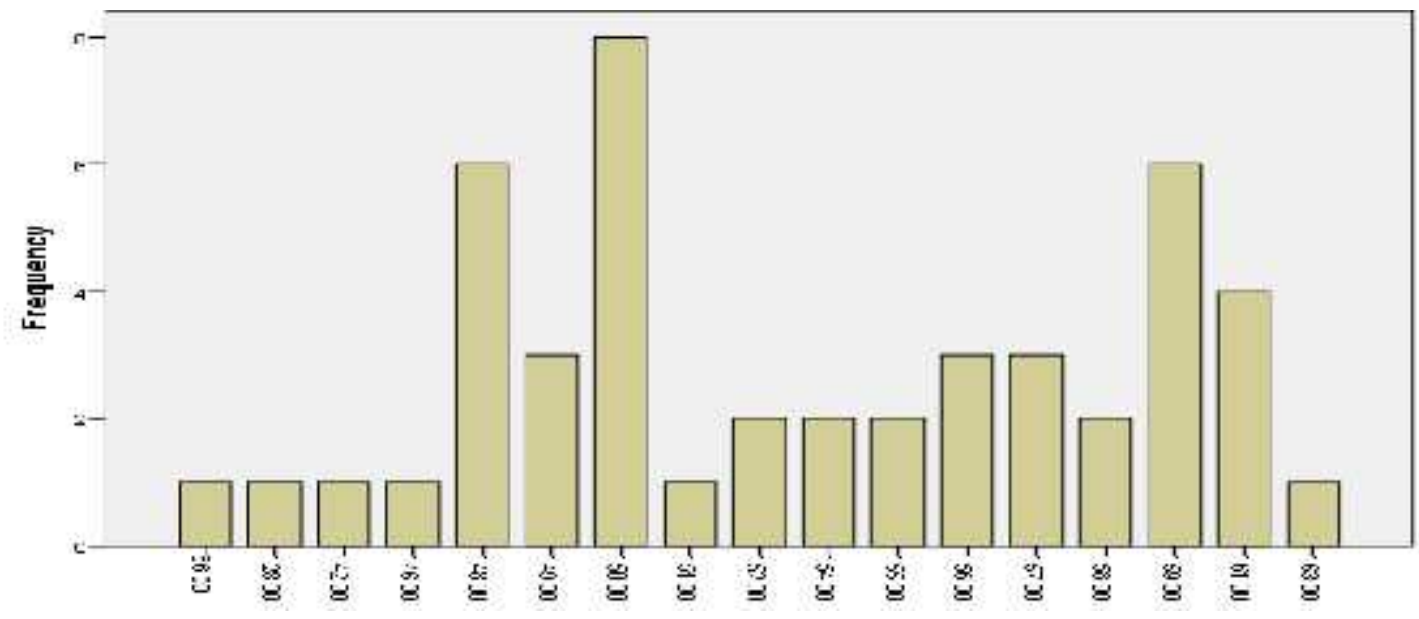

Gambar 3. Grafik Batang Variabel Kinerja Pegawai

Berdasarkan Gambar 3 dapat dijelaskan bahwa frekuensi terkecil sebesar 1 atau 2,1\% terdapat pada nilai 86, 128, 142, 146, 151, dan 163 Selanjutnya frekuensi terbesar sebesar 8 atau $17 \%$ terdapat pada nilai 150 .

Pengujian Persyaratan Analisis. Ada dua persyaratan analisis yang harus dilakukan dengan data yang telah didapat sebelum menentukan teknik analisis dalam melakukan pengujian hipotesis yaitu: 1) Uji Normalitas, dan 2) Uji Homogenitas Uji analisis sesuai di atas dapat dilihat dibawah ini:

1. Uji Normalitas Galat Taksiran. Teknik statistik yang digunakan untuk menganalisis data hasil pengukuran suatu kasus, umumnya disandarkan pada asumsi bahwa data yang berskala interval akan berdistribusi normal. Ada beberapa cara untuk menguji normalitas tabulasi data. Uji normalitas galat taksiran dihitung skor selisih masing-masing dengan persamaan regresi dengan skor variabel Y. Pada penelitian uji normalitas digunakan uji Kolmogorov - Smirnov (Uji K-S), karena uji KS di nilai "More Powerful" dibanding uji lainnya, dengan total signifikansi ( $\alpha=0.05$ ). hipotesi statisik untuk uji normalitas sebagai berikut:

$$
\begin{aligned}
& \mathrm{H}_{0}=\text { Data Populasi Bedistribusi Normal } \\
& \mathrm{H}_{1}=\text { Data Populasi Tidak Brdistribusi Normal }
\end{aligned}
$$

Dengan keriteria pengujian sebagai berikut: (1) Jika signifikansi yang diperoleh $<\alpha$ maka data yang berasal dari populasi berdistribusi normal, (2) JIka signifikansi yang diperoleh $>\alpha$ maka data yang berasal dari populasi tidak berdistribusi normal. 
Perhitungan uji normalitas dilakukan dengan bantuan program SPSS, 18. terdapat pula pada Hasil rangkuman dapat dilihat pada Tabel dibawah ini.

Tabel 2. Rangkuman Uji Normalitas melalui Uji KS ( $\mathrm{n}=47)$

\begin{tabular}{|c|c|c|c|c|c|}
\hline No & Variabel Terikat & Variabel Bebas & $\begin{array}{c}\text { Signifikansi } \\
\text { nilai K-S }\end{array}$ & Signifikansi & Distribusi \\
\hline 1 & Kin & Ko & 0.002 & 0. & \\
\hline 2 & Kinerja Pegawai (Y) & Lingkungan Kerja $\left(\mathrm{X}_{2}\right)$ & 0.012 & 0.05 & Normal \\
\hline
\end{tabular}

Dari Tabel diatas hasil signifikasni nilai K-S ternyata lebih kecil dari signifikansi ( $\alpha$ $=0.05)$. dengan demikian dapat dikatakan hipotesis $\mathrm{H}_{0}$. diterima yang artinya data berasal dari distribusi normal.

2. Uji Homogenitas. Uji homogenitas bertujuan untuk menguji derajat perbedaan atau variasi nilai data individu dalam kumpulan data. Pada penelitian ini yang dimaksudkan adalah varians kelompok variabel terikat (Y) yang dikelompokan berdasarkan varibel bebas (X1, X2, dan Y). Hipotesis statistik untuk uji homogenitas adalah sebagai berikut: $\mathrm{H}_{0}=$ Variansi setiap kelompok homogen $\mathrm{H}_{1}=$ Variansi setiap kelompok tidak homogen

Kriteria pengujian adalah jika signifikansi based on mean yang diperoleh $>\alpha$, maka variansi populasi homogen dan sebaliknya jika signifikansi based on mean $<\alpha$, maka variansi populasi tidak homogen. Hasil perhitungan SPSS, 18. dapat diluhat sebagai berikut:

Tabel 3. Test of Homogeneity of Variances

\begin{tabular}{lrrrr}
\hline Variabel Bebas & $\begin{array}{c}\text { Levene } \\
\text { Statistic }\end{array}$ & df1 & df2 & \multicolumn{1}{c}{ Sig. } \\
\hline Kompetensi Manajerial & 1.036 & 10 & 30 & .008 \\
Lingkungan Kerja & 1.714 & 10 & 30 & .028 \\
\hline
\end{tabular}

Bedasarkan Tabel 3 terlihat harga signifikansi $0.028<(0.05)$ artinya hipotesisnya diterma yang berarti variable tersebut homogen, dengan kata lain populsinya homogen.

Pengujian Hipotesis. Hubungan Kompetensi dengan Kinerja Pegawai. Perumusan hipotesis pertama pada penelitian ini adalah terdapat hubungan Kompetensi dengan Kinerja Pegawai. setelah dilakukan pengujian persyaratan analisa melalui uji normalitas, homogenitas dan linieritas didapatkan perhitungan hubungan fungsional atas kedua variabel Kompetensi dengan Kinerja Pegawai diperoleh hasil sebagai berikut :

1. Sesuai dengan hipotesis statistik maka hubungan Kompetensi dengan Kinerja Pegawai dengan menggunakan teknik korelasi product moment diperoleh koefisien korelasi $r_{\mathrm{y} .1}$ $=0,879$ Dengan demikian jika di konsultasikan pada Tabel intervretasi tingkat hubungan $r_{\text {hitung }}=0,879$ tergolong pada katagori sangat signifikan

2. Kontribusi Kompetensi dengan Kinerja Pegawai dihitung berdasarkan koefisien determinasi yaitu $\mathrm{r}^{2}=\left(\mathrm{r}_{\mathrm{y} .1}\right)^{2}=0,773$ Berarti variabel Kompetensi membentuk kontribusi sebesar 77,3\% dengan Kinerja Pegawai. 
3. Berdasarkan hasil analisis bahwa tingkat signifikansi korelasi prodak moment sebesar 0,000, yang artinya bahwa hubungan Kompetensi dengan Kinerja Pegawai sangat signifikan

Hubungan Lingkungan Kerja dengan Kinerja Pegawai. Perumusan hipotesis kedua pada penelitian ini adalah terdapat hubungan positif Lingkungan Kerja dengan Kinerja Pegawai. setelah dilakukan pengujian persyaratan analisa melalui uji normalitas, homogenitas dan linieritas didapatkan perhitungan hubungan variabel Lingkungan Kerja dengan Kinerja Pegawai diperoleh hasil sebagai berikut :

1. Sesuai dengan hipotesis statistik maka hubungan Lingkungan Kerja dengan Kinerja Pegawai dengan menggunakan teknik korelasi product moment diperoleh koefisien korelasi $r_{\mathrm{y} .2}=0,701$ bila di konsultasikan pada Tabel intervretasi tingkat hubungan $r$ hitung $=0,701$ dapat dikatagorikan tingkat hubungan Lingkungan Kerja dengan Kinerja Pegawai dikatagorikan Sangat Signifikan.

2. Kontribusi Lingkungan Kerja dengan Kinerja Pegawai dihitung berdasarkan koefisien determinasi yaitu $r^{2}=\left(r_{y \cdot 2}\right)^{2}=0,491$. Berarti variabel Lingkungan Kerja membentuk kontribusi sebesar 49,1\% dengan Kinerja Pegawai .

3. Berdasarkan hasil analisis bahwa tingkat signifikansi korelasi prodak moment sebesar 0,000, yang artinya bahwa hubungan lingkungan kerja dengan Kinerja Pegawai sangat signifikan

Hubungan Kompetensi dan Lingkungan Kerja secara bersama-sama dengan Kinerja Pegawai. Hipotesis yang pertama yang diujikan adalah terdapatnya hubungan positif Kompetensi dan Lingkungan Kerja secara bersama-sama dengan Kinerja Pegawai.

1. Sesuai dengan hipotesis statistik maka hubungan kompetensi dan Lingkungan Kerja secara bersama-sama dengan kinerja pegawai dengan menggunakan teknik korelasi product moment diperoleh koefisien korelasi $r_{\mathrm{y} .2}=0,883>$ bila di konsultasikan pada tabel intervretasi tingkat hubungan $\mathrm{r}$ hitung $=0,883$ dapat dikatagorikan tingkat hubungan kompetensi dan lingkungan kerja secara bersama-sama dengan kinerja pegawai dikatagorikan sangat signifikan.

2. Kontribusi kompetensi dan lingkungan kerja secara bersama-sama dengan kinerja pegawai dihitung berdasarkan koefisien determinasi yaitu $r^{2}=\left(r_{y} \cdot 1.2\right)^{2}=0,780$. Berarti variabel kompetensi dan lingkungan kerja membentuk kontribusi sebesar $78 \%$ dengan kinerja pegawai.

3. Berdasarkan hasil analisis bahwa tingkat signifikansi korelasi prodak moment sebesar 0,000, yang artinya bahwa hubungan Kompetensi dan lingkungan kerja secara bersama-sama dengan Kinerja Pegawai sangat signifikan.

Hasil penelitian membuktikan bahwa terdapat hubungan positif dan sangat signifikan Kompetensi dengan Kinerja Pegawai. Kekuatan hubungan Kompetensi dengan Kinerja Pegawai dapat dilihat dari nilai koefesien korelasi $\left(r_{y 1}\right)$ sebesar 0,879 , menunjukkan hubungan yang sangat kuat kedua variabel tersebut. Nilai koefesien determinasi $\left(\mathrm{r}_{\mathrm{y} 1}\right)^{2}$ sebesar 0,773 hal ini berarti varians Kinerja Pegawai dapat dijelaskan oleh varians Kompetensi sebesar 77,3\% sedangkan selebihnya berhubungan dengan variabel lain. Bentuk hubungan Kompetensi dengan Kinerja Pegawai ditunjukkan oleh persamaan regresi di mana secara kuantitatif dapat dikatakan bahwa setiap penambahan variabel Kompetensi akan meningkatkan variabel Kinerja Pegawai. Dengan demikian, untuk 
meningkatkan Kinerja Pegawai dapat dilakukan dengan meningkatkan Kompetensi. Semakin tinggi Kompetensi para pegawai dalam bekerja akan mempunyai kinerja yang tinggi. Hasil penelitian membuktikan bahwa terdapat hubungan sangat signifikan Lingkungan Kerja dengan Kinerja Pegawai.

Kekuatan hubungan Lingkungan Kerja dengan Kinerja Pegawai dapat dilihat dari nilai koefesien korelasi $\left(\mathrm{r}_{\mathrm{y} 2}\right)$ sebesar 0,701 menunjukkan hubungan yang sangat kuat kedua variabel tersebut. Nilai koefisien determinasi $\left(r_{\mathrm{y} 2}\right)^{2}$ sebesar 0,491 hal ini berarti varians Kinerja Pegawai dapat dijelaskan oleh varians Lingkungan Kerja sebesar 49,1\% sedangkan selainnya berhubungan dengan variabel lain. Bentuk hubungan Lingkungan Kerja dengan Kinerja Pegawai ditunjukkan oleh persamaan regresi di mana secara kuantitatif dapat dikatakan bahwa setiap penambahan variabel Lingkungan Kerja akan meningkatkan Kinerja Pegawai. Dengan demikian, untuk meningkatkan Kinerja Pegawai dapat dilakukan dengan meningkatkan Lingkungan Kerja. Semakin baik Lingkungan Kerja akan semakin tinggi Kinerja Pegawai.

Hasil penelitian membuktikan bahwa terdapat hubungan positif dan sangat signifikan Kompetensi dan Lingkungan Kerja dengan Kinerja Pegawai. Kekuatan hubungan Kompetensi dan Lingkungan Kerja dengan Kinerja Pegawai dapat dilihat dari nilai koefesien korelasi $\left(\mathrm{r}_{\mathrm{y} 1.2}\right)$ sebesar 0,883, menunjukkan hubungan yang sangat signifikan variabel bebas dengan variabel terikatnya. Nilai koefesien determinasi $\left(\mathrm{r}_{\mathrm{y} 2}\right)$ sebesar 0,780 hal ini berarti varians Kinerja Pegawai dapat dijelaskan oleh varians Kompetensi dan baik Lingkungan Kerja secara bersama-sama sebesar $78 \%$ sedangkan $22 \%$ berhubungan dengan variabel lain. Bentuk hubungan Kompetensi dan baik Lingkungan Kerja pegawai dengan Kinerja Pegawai ditunjukkan oleh persamaan regresi yang menyatakan bahwa semakin tinggi variabel Kompetensi dan Lingkungan Kerja maka akan semaikn tinggi juga Kinerja Pegawai.

\section{PENUTUP}

Simpulan. Berdasarkan hasil pengujian hipotesis dan pembahasan hasil penelitian diperoleh kesimpulan sebagai berikut: (1) Hubungan kompetensi dengan kinerja pegawai dengan menggunakan teknik korelasi product moment diperoleh koefisien korelasi $\mathrm{r}_{\mathrm{y} .1}=$ 0,879 tergolong pada katagori sangat signifikan, (2) Hubungan lingkungan kerja dengan kinerja pegawai dengan menggunakan teknik korelasi product moment diperoleh koefisien korelasi $r_{y .2}=0,701$ dikatagorikan tingkat hubungan lingkungan kerja dengan kinerja pegawai dikatagorikan signifikan, (3) Hubungan kompetensi dan lingkungan kerja secara bersama-sama dengan kinerja pegawai dengan menggunakan teknik korelasi product moment diperoleh koefisien korelasi $\mathrm{r}_{\mathrm{y} .2}=0,883>$ bila di konsultasikan pada Tabel intervretasi tingkat hubungan $r_{\text {hitung }}=0,883$ dapat dikatagorikan tingkat hubungan Kompetensi Manajerial dan Lingkungan Kerja secara bersama-sama dengan Kinerja Pegawai dikatagorikan sangat signifikan

Saran. Berdasarkan kesimpulan dan implikasi penelitian dapat disarankan sebagai berikut: (1) Pegawai dalam menjalankan tugas yang diberikan oleh Pimpinan dilakukan dengan penuh tanggungjawab dengan demikian kepercayaan Pimpinan bertambah sehingga kepemimpinan yang dijalankan oleh Pimpinan dapat ditingkatkan guna peningkatan Kinerja Pegawai, (2) Pegawai mempunyai sikap yang adil dan disiplin dalam 
bekerja, (3) Pegawai hendaklah terus belajar untuk meningkatkan kompetensi yang dimiliki. Pegawai yang memiliki kompetensi pekerjaan yang baik sangat membantu dalam menghasilkan kinerja yang lebih baik. Untuk itu Lingkungan Kerja terus ditingkatkan, (4) Dalam setiap akhir pekerjaan pegawai memberikan evaluasi, (5) Pimpinan memberikan bimbingan dan motivasi kepada pegawai agar bekerja lebih giat lagi, (6) Pimpinan harus dapat menciptakan situasi kerja yang kondusif. Penataan lingkungan kerja disertai upaya mengoptimalkan sumber daya kantor dapat membuat pegawai menjadi semangat dalam melaksanakan pekerjaan sehingga Kinerja Pegawai semakin meningkat, (7) Untuk memelihara dan memantapkan Kinerja Pegawai, maka perlu diadakan forum pertemuan seluruh pegawai secara berkala dan rutin sebagai media bagi pegawai untuk memperoleh informasi-informasi yang baru.

\section{DAFTAR RUJUKAN}

Agus, Dharma, (2003) Manajemen Supervisi edisi IV, Jakarta: Erlangga

Arikunto, Suharsimi. (2002) Prosedur Penelitian Survai: Bandung: Remaja Rosda Karya

Arif, Nur Rianto. (2010) "Prilaku Konsumen Muslim dalam Memaksimumkan Kepuasan. Yogyakarta", Jurnal Sosio-Religia Link SAS. Terakreditasi No. 108/DIKTI/Kep./2007

Asrin, (2011) Paradigma Manajemen Pendidikan. Gorontalo: Ideas Publishing

Asrin. (2009) Profesionalisme Manajemen Birokrasi. Gorontalo: Ideas Publishing

Brammer, L.M dan Shostrom, E.L. (1982) Therapeutic Psychology: Fundamental of Counseling and Psychoterapy: Fourth Edition. New Jersey: Prentice Hall Inc.

Corey, Gerald. (2005) Theory and Practice of Counseling and Psychotheraphy: Seventh edition. Belmont, CA: Brooks/Cole-Thompson Learning

Edgar, Schein, H. (2009) "Organizational Culture \& Leadership". (http://www.tnellen.com/ted/tc/schein.html) MIT Sloan Management Review.

Geldard, David. (1993) Basic Personal Counseling: Second Edition. Sydney: Prentice Hall.

Gerald. Corey. (2004) Theory and Practice of Counseling and Psychotherapy. Monterey, California: Brooks/Cole Publishing Company

Hadari, Nawawi, (2006) Evaluasi dan Manajemen Kinerja di Lingkungan Perusahaan dan Industri, Yogyakarta: Gajah Mada University Press.

Hein, George E. (1991) Contructivist Theory Learning, Massachusets USA. Lesley College. Massachusetts USA

John P. Kotter. \& James L. Heskett, (1998) Corporate Culture and Performance. (terj Benyamin Molan). Jakarta: PT Prehalindo.

Mangkunegara, Anwar, Prabu, AA. (2007) Evaluasi Kinerja Sumberdaya Manusia. Bandung: Rafika Aditama

Nawawi, Hadari. (2006) Evaluasi dan Manajemen Kinerja di Lingkungan Perusahaan dan Industri. Yogyakarta: Gadjah Mada University.

Rajasa, Hatta. (2007) Membangun Kinerja dan Kemandirian Bangsa (makalah). /www.Setneg. go.id.

Rudman. (2000) Learning Counseling and Problem Solving Skills. New York: The Hawarth Press. 
Ruky, Achmad, S, (2002) Sistem Manajemen Kinerja. Jakarta: PT. Gramedia Pustaka Utama

Schein, Edgar H. "Organizational Culture \& Leadership". (http://www.tnellen.com/ted/tc/schein.html) MIT Sloan Management Review.

Sharker, P.R. 2006. Neohumanisme.http://www.nhe. pegawaikul.edu/htm.

Smith, L. Andraw. (2006) A Study of The Relatiionship Between School Culture and Standarized Test Scoress, PdF. University of Phonix ,USA.

Soeprihanto, Jhon, (2001) Penilaian Kinerja dan Pengembangan Karyawan, Yogyakarta: BPFE Yogyakarta.

Supeni, Siti. (2012) "Evaluasi Nilai Kepemimpinan Budaya Jawa dalam Pandangan dan Prilaku Kepala Sekolah Dasar”. Yogyakarya: Jurnal Penelitian dan Evaluasi Pendidikan. Terakreditasi Dikti No. 64a/DIKTI/Kep/2010

Wirawan, (2009) Evaluasi Kinerja Sumber Daya Manusia: Teori, Aplikasi, dan Penelitian, Jakarta: Salemba Empat. 